\title{
Transforming growth factor $\beta$ signaling in uterine development and function
}

Qinglei Li

\begin{abstract}
Transforming growth factor $\beta$ (TGF $\beta$ ) superfamily is evolutionarily conserved and plays fundamental roles in cell growth and differentiation. Mounting evidence supports its important role in female reproduction and development. TGFBs1-3 are founding members of this growth factor family, however, the in vivo function of TGF $\beta$ signaling in the uterus remains poorly defined. By drawing on mouse and human studies as a main source, this review focuses on the recent progress on understanding TGF $\beta$ signaling in the uterus. The review also considers the involvement of dysregulated TGF $\beta$ signaling in pathological conditions that cause pregnancy loss and fertility problems in women.
\end{abstract}

Keywords: Decidualization, Development, Embryonic development, Implantation, Myometrium, Pregnancy, Transforming growth factor $\beta$, Uterus

\section{Introduction}

Transforming growth factor $\beta$ (TGF $\beta$ ) superfamily proteins are versatile and fundamental regulators in metazoans. The TGF $\beta$ signal transduction pathway has been extensively studied. The application of mouse genetic approaches has catalyzed the identification of the roles of core signaling components of TGF $\beta$ superfamily members in reproductive processes. Recent studies using tissue/cellspecific knockout approaches represent a milestone towards understanding the in vivo function of TGF $\beta$ superfamily signaling in reproduction and development. These studies have yielded new insights into this growth factor superfamily in uterine development, function, and diseases. This review will focus on TGF $\beta$ signaling in the uterus, primarily using results from studies with mice and humans.

\section{TGF $\beta$ superfamily}

\section{Core components of the TGF $\beta$ signaling pathway}

Core components of the TGF $\beta$ signaling pathway consist of ligands, receptors, and SMA and MAD (mother against decapentaplegic)-related proteins (SMAD). TGF $\beta$ ligands

Correspondence: qli@cvm.tamu.edu

Department of Veterinary Integrative Biosciences, College of Veterinary

Medicine and Biomedical Sciences, Texas A\&M University, College Station, TX 77843, USA bind to their receptors and impinge on SMADs to activate gene transcription. TGF $\beta$ superfamily ligands include TGF $\beta$ s, activins, inhibins, bone morphogenetic proteins (BMPs), growth differentiation factors (GDFs), antiMüllerian hormone (AMH), and nodal growth differentiation factor (NODAL). Seven type I (i.e., ACVRL1, ACVR1, BMPR1A, ACVR1B, TGFBR1, BMPR1B, and ACVR1C) and five type II receptors (i.e., TGFBR2, ACVR2, ACVR2B, BMPR2, and AMHR2) have been identified [1-4]. SMADs are intracellular transducers. In mammalian species, eight SMAD proteins have been identified and are classified into receptor-regulated SMADs (R-SMADs; SMAD1, 2, 3, 5, and 8), common SMAD (CoSMAD), and inhibitory SMADs (I-SMADs; SMAD6 and SMAD7). R-SMADs are tethered by SMAD anchor for receptor activation (SARA) [5]. In general, SMAD1/5/8 mediate BMP signaling, whereas SMAD2/3 mediate TGF $\beta$ and activin signaling. SMAD6 and SMAD7 can bind type I receptors and inhibit TGF $\beta$ and/or BMP signaling $[6,7]$. A plethora of ligands versus a fixed number of receptors and SMADs suggests the usage of shared receptor(s) and SMAD cell signaling molecules in this system.

\section{TGF $\beta$ signaling paradigm: canonical versus non-canonical pathway}

To initiate signal transduction, a ligand forms a heteromeric type II and type I receptor complex, where the 
constitutively active type II receptor phosphorylates type I receptor at the glycine and serine (GS) domain. Subsequent phosphorylation of R-SMADs by the type I receptor and formation and translocation of R-SMAD-SMAD4 complex to the nucleus are critical steps for gene regulation [2,8-10]. Activation of transcription is achieved by SMAD binding to the consensus DNA binding sequence (AGAC) termed SMAD binding element (SBE) [11,12], in concert with co-activators and co-repressors. Of note, SMADs can promote chromatin remodeling and histone modification, which facilitates gene transcription by recruiting co-regulators to the promoters of genes of preference [13].

TGF $\beta$ signals through both SMAD-dependent (i.e., canonical) and SMAD-independent (i.e., non-canonical) pathways in a contextually dependent manner [2,8,14-16] (Figure 1). The non-canonical pathways serve to integrate signaling from other signaling cascades, resulting in a quantitative output in a given context. Davis and colleagues [17] have recently suggested the presence of microRNA (miRNA)-mediated non-canonical pathway, where TGF $\beta$ signaling promotes the biosynthesis of a subset of miRNAs via interactions between R-SMADs and a consensus RNA sequence of miRNAs within the DROSHA (drosha, ribonuclease type III) complex [17-19]. Thus, this type of noncanonical signaling requires R-SMADs but not SMAD4. Multiple regulatory layers including ligand traps (e.g., follistatin), inhibitory SMADs, and interactive pathways exist to determine the signaling output and precisely control TGF $\beta$ signaling activity $[4,8,20-23]$. For instance, the linker region of R-SMADs is subject to the phosphorylation modification by mitogen-activated protein kinases (MAPKs) [24].
Therefore, the variable responses triggered by this growth factor superfamily and the complex signaling circuitries within a given cell population underscore the importance of a fine-tuned TGF $\beta$ signaling system at both the cellular and systemic levels.

\section{TGF $\beta$ superfamily signaling regulates female reproduction}

TGF $\beta$ superfamily is evolutionarily conserved and plays fundamental roles in cell growth and differentiation. The signal transduction and biological functions of this signaling pathway have been extensively investigated $[2,4,8,9,25]$. TGF $\beta$ superfamily signaling is essential for female reproduction (Figure 2), and dysregulation of TGF $\beta$ signaling may cause catastrophic consequences, leading to reproductive diseases and cancers [26-33].

Recent studies have uncovered the roles of key receptors and intracellular SMADs of this pathway in female reproduction. Smad1 and Smad5 null mice are embryonically lethal, but Smad8 null mice are viable and fertile [34,35]. SMAD1/5 and ALK3/6 act as tumor suppressors with functional redundancy in the ovary $[27,29]$. Smad $3^{\Delta \text { ex8 }}$ mice demonstrate impaired follicular growth and atresia, altered ovarian cell differentiation, and defective granulosa cell response to follicle-stimulating hormone (FSH) [36,37]. We have shown that SMAD2 and SMAD3 are redundantly required to maintain normal fertility and ovarian function [38]. Disruption of Smad4 signaling in ovarian granulosa cells leads to premature luteinization [39]. However, oocyte-specific knockout of Smad4 causes minimal fertility defects in mice [40]. SMAD7 mediates TGF $\beta$ induced apoptosis [41] and antagonizes key TGF $\beta$ signaling in ovarian granulosa cells [42], suggesting inhibitory

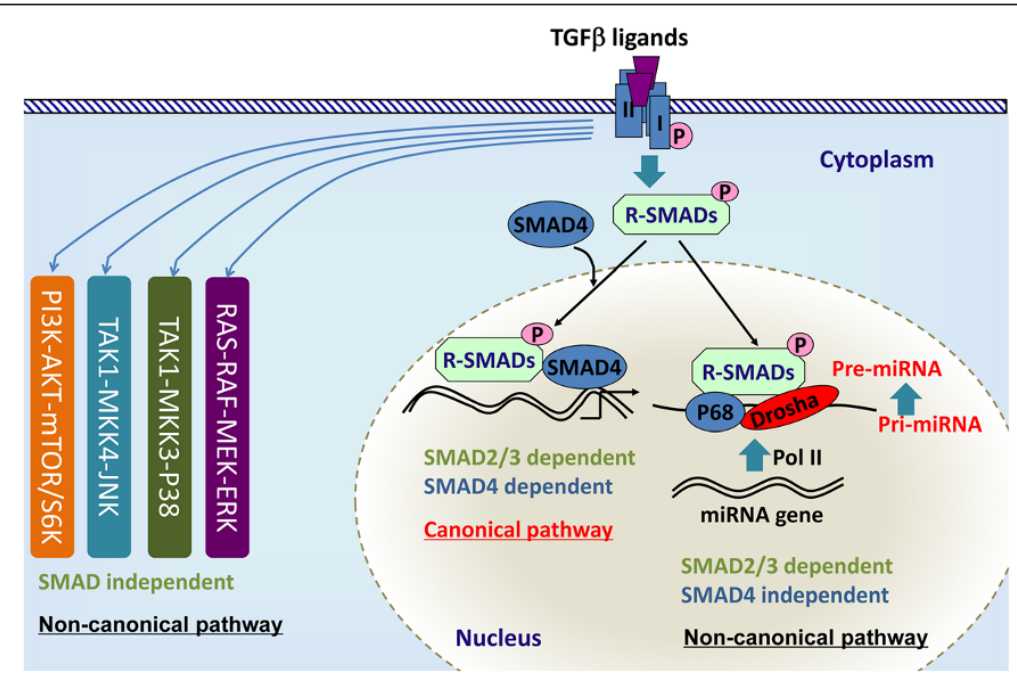

Figure 1 Canonical and non-canonical TGF $\beta$ signaling. In the canonical pathway, TGF $\beta$ ligands bind to serine/threonine kinase type II and type I receptors and phosphorylate R-SMADs, which form heteromeric complexes with SMAD4 and translocate into the nucleus to regulate gene transcription. The non-canonical pathway generally refers to the SMAD-independent pathway such as PI3K-AKT, ERK1/2, p38, and JNK pathways. Recent studies have identified an "R-SMAD-dependent but SMAD4-independent" non-canonical pathway that regulates miRNA maturation. 


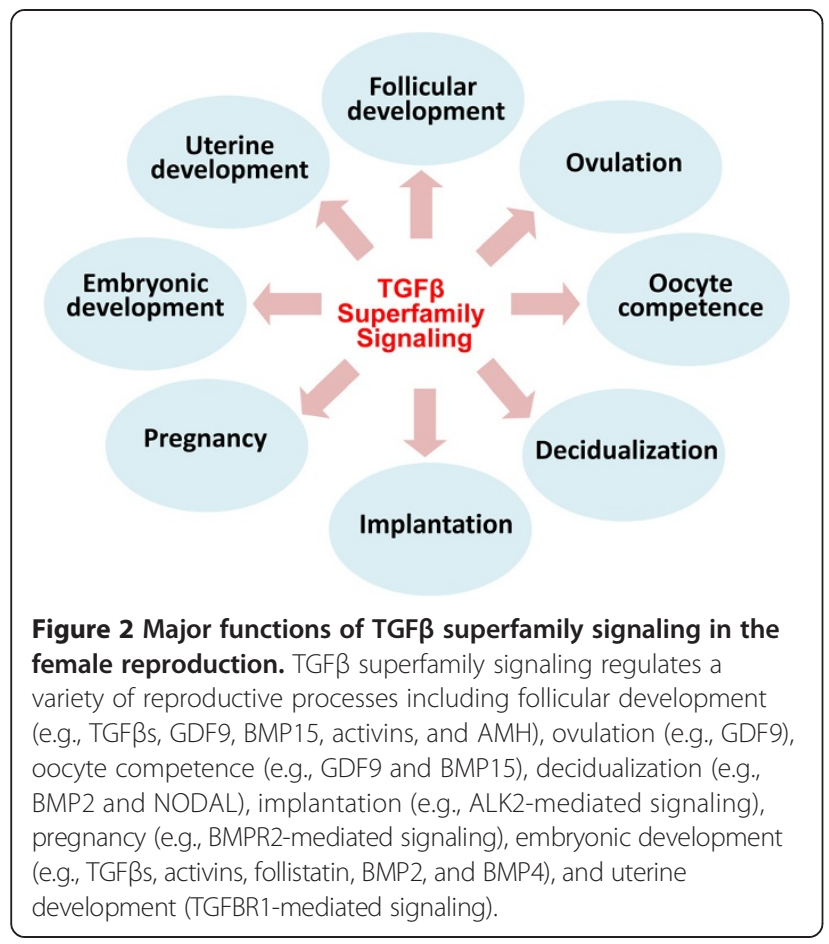

SMADs are potentially novel regulators of ovarian function. Recent studies show that TGFBR1 is indispensable for female reproductive tract development $[43,44]$, while ALK2 and BMPR2 are required for uterine decidualization and/or pregnancy maintenance $[45,46]$.

\section{TGF $\beta$ signaling in uterine development}

The uterus develops from the Müllerian duct, which forms at embryonic day E11.75 in mice [47]. Uterine mesenchymal cells remain randomly oriented and undifferentiated until after birth. Between birth and postnatal day 3, circular and longitudinal myometrial layers are differentiated from the mesenchyme [48]. The uterus acquires basic layers and structures by postnatal day $15[48,49]$. Maturation of the myometrium continues into adulthood. Mechanisms controlling myometrial development are poorly defined. Wingless-type MMTV integration site family (Wnt)7a null females demonstrate defects in reproductive tract formation, suggesting a critical role of Wnt $/ \beta$ catenin signaling in myometrial development [50-53].

Myometrial contractility is critical for successful pregnancy and labor. The myometrial cells transform from a quiescent to a contractile phenotype trigged by the decline of progesterone levels during late pregnancy. What has long puzzled scientists is how this transformation occurs during pregnancy, and how myometrial development and function are coordinately regulated. Uterine contraction is controlled by hormonal, cellular, and molecular signals [54-65]. Recent studies have discovered that miRNAs are key regulators of contraction-associated genes and suppressors including oxytocin receptor (Oxtr), cyclooxygenase 2 (Cox2), connexin 43 (Cx43), zinc finger E-box binding homeobox 1 (Zeb1), and Zeb2 [65,66]. However, signaling pathways that control the development of morphologically normal and functionally competent myometrium are poorly understood.

TGF $\beta$ signaling plays a pleiotropic role in fundamental cellular and developmental events [2,3,8]. Using a Tgfbr1 conditional knockout (cKO) mouse model created using anti-Müllerian hormone receptor type 2 (Amhr2)-Cre, we have shown that TGF $\beta$ signaling is essential for smooth muscle development in the female reproductive tract $[43,44]$. The female mice develop a striking oviductal phenotype that includes a diverticulum. The Tgfbrl cKO mice are infertile and embryos are unable to be transported to the uterus due to the presence of the physical barrier of oviductal diverticula [43]. Meanwhile, disrupted uterine smooth muscle formation is another prominent feature in these mice, which is associated with a developmental failure of the myometrium during early postnatal uterine development [44]. However, the expression of the majority of smooth muscle genes in the uterus of the conditional knockout mice does not significantly differ from that of controls, suggesting that the developmental abnormality might not be a direct result of intrinsic deficiency in smooth muscle cell differentiation. Our studies point to the contributions of reduced deposition of extracellular matrix proteins, derailed signaling of plateletderived growth factors, and potentially altered migration of uterine cells during a critical time window of development [44]. The Tgfbr1 cKO mouse model can be further exploited to understand the pathogenesis of myometriumassociated diseases, such as adenomyosis that is present in these mice [44].

\section{TGF $\beta$ signaling and uterine function}

Pre-implantation embryonic development refers to a period from fertilization to blastocyst implantation, which requires coordinated expression of maternal and embryonic genes. The fertilized egg undergoes dynamic genetic programming and divisions to reach the blastocyst stage. The pluripotent inner cell mass of the blastocyst will develop into the embryonic proper, while the trophectoderm and the primitive endoderm form extra-embryonic tissues during development [67]. Preimplantation embryonic development largely depends on maternal proteins and transcripts before zygotic genome activation (ZGA), which initiates the expression of genes that are needed for continued development of the embryos. ZGA occurs at the twocell stage in the mouse [68].

Blastocyst implantation is a complex event that is controlled by both intrinsic embryonic programs and extrinsic cues including hormonal and uterine signals. Implantation in the mouse can be divided into three phases: apposition, 
attachment, and penetration. Following attachment, uterine stromal cells extensively proliferate and differentiate into decidual cells (i.e., decidualization) [69]. The roles of steroid hormones, cytokines, growth factors, integrins, and angiogenic factors have been explored, and more recently, a number of novel genes/pathways underlying implantation have been identified. Several elegant reviews are available on these topics [70-72]. The important roles of embryonic TGF $\beta$ superfamily signaling in embryo development have been reviewed [3]. This article will focus on the role of maternal TGF $\beta$ signaling in implantation and embryonic development.

TGFBs1-3 are founding members of the TGF $\beta$ superfamily. The majority of currently available studies are confined to the identification of tissue/cell-specific expression of TGFBs and in vitro analysis of the ligand function. In the uterus, the in vivo role of TGF $\beta$ signaling remains elusive, partially because of the redundancy of the ligands $[73,74]$ and the lack of appropriate animal models as a result of the embryonic lethality in mice lacking TGF $\beta$ ligands. TGFB1 is involved in preimplantation development and yolk sac vasculogenesis/hematopoiesis [75]. To allow the $T g f b 1$ null mice survive to reproductive age, they were bred onto the severe combined immunodeficiency (SCID) background [76]. Although the uterus of $T g f b 1$ mutant mice appears to be morphologically normal [76], embryos are arrested in the morula stage.

An in vitro model has been used to determine the effect of growth factors on preimplantation development, and the results showed that TGFB1 or epidermal growth factor (EGF) dramatically improves the inferior development of singly cultured embryos between eight-cell/morula and blastocyst stages. This study suggests that embryo and/ or reproductive tract-derived growth factors are involved in the development of preimplantation embryos [77]. In vitro treatment of preimplantation stage embryos with TGFB1 increases total numbers of cells in expanded and hatching blastocysts [78]. Furthermore, TGFB1-promoted in vitro blastocyst outgrowth is blocked by an antibody directed to parathyroid hormone-related protein [79], which suggests the involvement of parathyroid hormone-related protein in mediating the effect of TGFB1 on blastocyst outgrowth. In addition, TGFB1 increases the in vitro expression of oncofetal fibronectin, an anchoring trophoblast marker, indicating a potential role of TGF $\beta$ in trophoblast adhesion during implantation [80]. TGFB1 also inhibits human trophoblast cell invasion, at least partially, by promoting the production of tissue inhibitor of metalloproteinases (TIMP) [81]. An elegant study showed that maternal TGFB1 can cross the placenta and rescue the developmental defects of $T g f b 1$ null embryos, leading to perinatal survival of these mice [82]. As further evidence, both maternal and fetal TGFB1 may act to maintain pregnancy [83].

\section{TGF $\beta$ signaling and uterine diseases \\ Uterine fibroids}

Leiomyoma, generally known as uterine fibroid, is a benign tumor arising from the myometrium (i.e., smooth muscle layers). Although leiomyoma is commonly benign, it could be the cause of fertility disorders and morbidity and mortality in women [84].

Increasing lines of evidence point to the involvement of TGF $\beta$ signaling in the development of leiomyoma. It has been shown that the expression of TGFBs and receptors is elevated in leiomyomata versus unaffected myometrium [85]. Among all the three TGF $\beta$ isoforms, TGFB3 seems to play a major role in leiomyoma development by promoting cell growth and fibrogenic process [86]. Tgfb3 transcript and protein levels are elevated in human leiomyoma cells, compared with myometrial cells in two-dimensional (2D) and 3D cultures [87-90]. In a 3D culture system, a higher level of TGFB3 and SMAD2/3 activation is present in the leiomyoma cells versus myometrial cells $[87,89]$. However, it does not support that connective tissue growth factor 2 (CCN2/CTGF) is a major mediator of TGF $\beta$ action in leiomyoma tissues [91].

Although a link between overexpression of TGFBs and leiomyoma has been recognized, the precise mechanisms of TGF $\beta$ signaling in leiomyoma are largely unknown. It has been demonstrated that TGFB1-stimulated expression of fibromodulin may contribute to the fibrotic properties of leiomyoma [92]. Moreover, treatment of myometrial cells with TGFB3 promotes the expression of ECM components such as collagen 1A1 (COL1A1), fibronectin 1 (FN1), and versican, but reduces the expression of those associated with ECM degradation $[88,93]$. Thus, TGF $\beta$ signaling induces molecular changes that facilitate leiomyoma formation. Consistent with the enhanced TGF $\beta$ signaling in the etiology of leiomyoma, a number of substances or drugs, such as genistein [94], relaxin [95], halofuginone [96], asoprisnil [97], gonadotropin-releasing hormone-analogs (GnRH-a), and tibolone [98] may influence leiomyoma development via affecting TGF $\beta$ signaling. For the therapeutic purpose, an ideal drug is one that only targets TGF $\beta$ signaling in the leiomyoma cells but not normal myometrial cells. In this vein, asoprisnil, a steroidal 11ß-benzaldoximesubstituted selective progesterone receptor modulator (SPRM), targets TGFB3 and TGFBR2 in leiomyoma cells but not normal myometrial cells [97], providing a potentially effective treatment option for leiomyoma. The high levels of leiomyoma-secreted TGFBs, in turn, may compromise uterine function of the patients. For example, by producing excessive amount of TGFB3, leiomyoma antagonizes decidualization mediated by BMP2 [99].

\section{Preeclampsia}

Preeclampsia often occurs in pregnant women after the $20^{\text {th }}$ week of gestation, characterized by hypertension and 
proteinuria. The causes of preeclampsia are complex and beyond the scope of this review. It has been shown that plasma TGFB1 [100-104] and TGFB2 [105] levels are elevated in patients with preeclampsia. Experimental evidence also suggests that failure to downregulate the expression of TGFB3 during early gestation may cause trophoblast hypoinvasion and preeclampsia [106]. Interestingly, the levels of soluble endoglin, a transmembrane TGF $\beta$ co-receptor, are elevated in sera of women with preeclampsia, which may be associated with vascular complications and hypertension in these patients $[107,108]$. Based on these findings, TGFB proteins may serve as potential biomarkers for preeclampsia [105]. It is thus plausible that optimal TGF $\beta$ signaling activity is required to keep preeclampsia in check by maintaining normal trophoblast invasion during implantation and placentation. However, another study showed that TGFBs1-3 are not expressed in villous trophoblasts, and TGFB1 and TGFB3 are not expressed in the extravillous trophoblast either. The expression of TGFBs1-3 in the placenta is not altered in patients with preeclampsia [109]. Moreover, there are also reports indicating that concentrations of TGFB1 in serum are indistinguishable between patients with preeclampsia and normal controls [110-112]. In addition, the levels of activin A and inhibin $\mathrm{A}$, but not inhibin $\mathrm{B}$, are increased in patients with preeclampsia [113-116]. Thus, the role of TGF $\beta$ signaling in the pathophysiological events of preeclampsia awaits further elucidation.

\section{Intrauterine growth restriction}

Intrauterine growth restriction (IUGR), also called fetal growth restriction (FGR), refers to a complication of fetal growth during pregnancy. The estimated weight of the fetus with IUGR is often less than $90 \%$ of other fetuses at the same stage of pregnancy [117]. Circumstantial evidence indicates that TGF $\beta$ signaling is involved in the development of IUGR. Serum levels of TGFB1 in the IUGR fetus are lower [118]. TGFB2 is required for normal embryo growth, as supported by the fact that Tgfb2 mutant fetuses weigh less than littermate controls [119]. Soluble endoglin levels are elevated in IUGR pregnancies [108], although it is debatable [120]. It has been shown that the higher expression of endoglin in IUGR pregnancies may be caused by placental hypoxia involving TGFB3 [121]. Mouse models for IUGR are valuable to study the mechanism of this pathological condition, which may have devastating effects on the pregnancy and newborns. Notably, Nodal knockout mice show diminished decidua basalis due to reduced proliferation and enhanced apoptosis as well as defects in placental development, resulting in IUGR and preterm fetal loss [122]. Conditional ablation of Bmpr2 in the uterus causes defects in decidualization, trophoblast invasion, and vascularization, which are causes of IUGR in the pregnant females [46].

\section{Endometrial hyperplasia}

Endometrial hyperplasia is a pathological condition where endometrial cells undergo excessive proliferation [123]. Categories of endometrial hyperplasia include simple hyperplasia, simple atypical hyperplasia, complex hyperplasia, and complex atypical hyperplasia [124]. Endometrial hyperplasia is recognized as a premalignant lesion of endometrial carcinoma [125] and a potential cause of abnormal uterine bleeding and fertility disorders. The high prevalence of endometrial carcinoma is associated with atypical hyperplasia in women [126-128]. It has been reported that up to $29 \%$ of untreated complex atypical hyperplasia progresses to carcinoma [124]. Endometrial hyperplasia is generally caused by excessive or chronic estrogen stimulation that is unopposed by progesterone, as in patients with chronic anovulation and polycystic ovary syndrome. Although progestin treatment is commonly effective for this disease [129], approximately $30 \%$ of patients with complex hyperplasia are progestin resistant [130]. Genetic alterations including mutations of Pten tumor suppressor have been shown to be associated with endometrial hyperplasia $[131,132]$. Elegant work has shown that inactivation of TGF $\beta$ signaling and loss of growth inhibition are associated with human endometrial carcinogenesis [133,134]. The role of TGF $\beta$ signaling in endometrial cancer has been reviewed and will not be covered in this article [135]. Our recent study shows that loss of TGFBR1 in the mouse uterus using Amhr2-Cre enhances epithelial cell proliferation. The aberration culminates in endometrial hyperplasia. Further studies have uncovered potential TGFBR1mediated paracrine signaling in the regulation of uterine epithelial cell proliferation, and provided genetic evidence supporting the role of uterine epithelial cell proliferation in the pathogenesis of endometrial hyperplasia [136]. Further elucidating the role and the underlying mechanisms of TGF $\beta$ signaling in the pathogenesis of endometrial hyperplasia and/or cancer will benefit the design of new therapies.

\section{Conclusions and future directions}

A precisely controlled endogenous TGF $\beta$ signaling system is of critical importance for the development and function of female reproductive tract. Mouse genetics has proven to be a powerful tool to address many of the fundamental questions posed in the field of TGF $\beta$ and reproduction. Conditional knockout approaches have been utilized over the last two decades to decipher the reproductive function of TGF $\beta$ superfamily in female reproduction. These studies are at an exciting stage and are advancing at a rapid pace. The functional role of TGF $\beta$ signaling in the uterus is beginning to be unveiled. We anticipate that the genetic approach will continue to have large impacts and lead to new breakthroughs in this field. However, understanding how the hormonal, cellular, and molecular signals induce 
a specific biological response and functional outcome in the context of the uterine microenvironment in vivo represents a challenging task. It remains unclear how specific or integrated signals act on the chromatin to shape the epigenetic landscape in physiological and/or pathological conditions of the uterus. Therefore, the interaction between TGF $\beta$ signaling and other regulatory pathways (e.g., small RNA pathways) and potential epigenetic mechanisms underlying specific reproductive processes and/or diseases in the uterus need to be clarified. This knowledge will help to design new treatment options for uterine diseases and fertility disorders.

\section{Competing interests}

The author declares that he has no competing interests.

\section{Author's contributions}

The author reviewed and analyzed the literature and wrote this paper.

\section{Acknowledgements}

The author thanks the great support and collaboration from colleagues at Texas A\&M University, especially Drs. Kayla Bayless, Gregory Johnson, Robert Burghardt, and Fuller Bazer. Several trainees (Yang Gao, Samantha Duran, Chao Wang, and Haixia Wen) in the author's lab have contributed to the related work. Yang Gao is also acknowledged for the assistance with literature review. Research in this area is supported by the National Institutes of Health grant R21HD073756 from the Eunice Kennedy Shriver National Institute of Child Health \& Human Development and the Ralph E. Powe Junior Faculty Enhancement Awards from Oak Ridge Associated Universities.

Received: 9 July 2014 Accepted: 28 October 2014

Published: 14 November 2014

\section{References}

1. Massague J: Receptors for the TGF-beta family. Cell 1992, 69:1067-1070.

2. Massague J: TGF-beta signal transduction. Annu Rev Biochem 1998, 67:753-791.

3. Chang H, Brown CW, Matzuk MM: Genetic analysis of the mammalian transforming growth factor- $\beta$ superfamily. Endocr Rev 2002, 23:787-823.

4. Schmierer B, Hill CS: TGFbeta-SMAD signal transduction: molecular specificity and functional flexibility. Nat Rev Mol Cell Biol 2007, 8:970-982.

5. Tsukazaki T, Chiang TA, Davison AF, Attisano L, Wrana JL: SARA, a FYVE domain protein that recruits Smad2 to the TGF beta receptor. Cell 1998 95:779-791.

6. Imamura T, Takase M, Nishihara A, Oeda E, Hanai J, Kawabata M, Miyazono K: Smad6 inhibits signalling by the TGF-beta superfamily. Nature 1997, 389:622-626.

7. Nakao A, Afrakhte M, Moren A, Nakayama T, Christian JL, Heuchel R, Itoh S, Kawabata M, Heldin NE, Heldin CH, ten Dijke P: Identification of Smad7, a TGFbeta-inducible antagonist of TGF-beta signalling. Nature 1997, 389:631-635.

8. Massague J: How cells read TGF-beta signals. Nat Rev Mol Cell Biol 2000, 1:169-178.

9. Massague J: TGFbeta signalling in context. Nat Rev Mol Cell Biol 2012, 13:616-630

10. Akhurst RJ, Hata A: Targeting the TGFbeta signalling pathway in disease. Nat Rev Drug Discov 2012, 11:790-811.

11. Jonk LC, Itoh S, Heldin CH, ten Dijke P, Kruijer W: Identification and functional characterization of a Smad binding element (SBE) in the JunB promoter that acts as a transforming growth factor-beta, activin, and bone morphogenetic protein-inducible enhancer. J Biol Chem 1998, 273:21145-21152.

12. Shi Y, Wang YF, Jayaraman L, Yang H, Massague J, Pavletich NP: Crystal structure of a Smad MH1 domain bound to DNA: insights on DNA binding in TGF-beta signaling. Cell 1998, 94:585-594.

13. Ross S, Cheung E, Petrakis TG, Howell M, Kraus WL, Hill CS: Smads orchestrate specific histone modifications and chromatin remodeling to activate transcription. Embo J 2006, 25:4490-4502.
14. Moustakas A, Heldin CH: Non-Smad TGF-beta signals. J Cell Sci 2005, 118:3573-3584.

15. Zhang YE: Non-Smad pathways in TGF-beta signaling. Cell Res 2009, 19:128-139.

16. Guo X, Wang XF: Signaling cross-talk between TGF-beta/BMP and other pathways. Cell Res 2009, 19:71-88.

17. Davis BN, Hilyard AC, Lagna G, Hata A: SMAD proteins control DROSHAmediated microRNA maturation. Nature 2008, 454:56-61.

18. Davis BN, Hilyard AC, Nguyen PH, Lagna G, Hata A: Smad proteins bind a conserved RNA sequence to promote microRNA maturation by Drosha. Mol Cell 2010, 39:373-384.

19. Davis-Dusenbery BN, Hata A: Smad-mediated miRNA processing: A critical role for a conserved RNA sequence. RNA Biol 2011, 8:71-76.

20. Attisano L, Wrana JL: Signal transduction by the TGF-beta superfamily. Science 2002, 296:1646-1647.

21. Derynck R, Zhang YE: Smad-dependent and Smad-independent pathways in TGF-beta family signalling. Nature 2003, 425:577-584.

22. Yan X, Liu Z, Chen Y: Regulation of TGF-beta signaling by Smad7. Acta Biochim Biophys Sin (Shanghai) 2009, 41:263-272.

23. Yan XH, Chen YG: Smad7: not only a regulator, but also a cross-talk mediator of TGF-beta signalling. Biochem J 2011, 434:1-10.

24. Pera EM, Ikeda A, Eivers E, De Robertis EM: Integration of IGF, FGF, and anti-BMP signals via Smad1 phosphorylation in neural induction. Genes Dev 2003, 17:3023-3028.

25. Wakefield LM, Hill CS: Beyond TGFbeta: roles of other TGFbeta superfamily members in cancer. Nat Rev Cancer 2013, 13:328-341.

26. Li Q, Graff JM, O'Connor AE, Loveland KL, Matzuk MM: SMAD3 regulates gonadal tumorigenesis. Mol Endocrinol 2007, 21:2472-2486.

27. Pangas SA, Li X, Umans L, Zwijsen A, Huylebroeck D, Gutierrez C, Wang D, Martin JF, Jamin SP, Behringer RR, Robertson EJ, Matzuk MM: Conditional deletion of Smad1 and Smad5 in somatic cells of male and female gonads leads to metastatic tumor development in mice. Mol Cell Biol 2008, 28:248-257.

28. Matzuk MM, Finegold MJ, Su JG, Hsueh AJ, Bradley A: Alpha-inhibin is a tumour-suppressor gene with gonadal specificity in mice. Nature 1992, 360:313-319.

29. Edson MA, Nalam RL, Clementi C, Franco HL, Demayo FJ, Lyons KM, Pangas SA, Matzuk MM: Granulosa cell-expressed BMPR1A and BMPR1B have unique functions in regulating fertility but act redundantly to suppress ovarian tumor development. Mol Endocrinol 2010, 24:1251-1266.

30. Middlebrook BS, Eldin K, Li X, Shivasankaran S, Pangas SA: Smad1-Smad5 ovarian conditional knockout mice develop a disease profile similar to the juvenile form of human granulosa cell tumors. Endocrinology 2009, 150:5208-5217.

31. Neptune ER, Frischmeyer PA, Arking DE, Myers L, Bunton TE, Gayraud B, Ramirez F, Sakai LY, Dietz HC: Dysregulation of TGF-beta activation contributes to pathogenesis in Marfan syndrome. Nat Genet 2003, 33:407-411

32. Huang XR, Chung AC, Wang XJ, Lai KN, Lan HY: Mice overexpressing latent TGF-beta1 are protected against renal fibrosis in obstructive kidney disease. Am J Physiol Renal Physiol 2008, 295:F118-F127.

33. Massague J: TGFbeta in Cancer. Cell 2008, 134:215-230.

34. Arnold SJ, Maretto S, Islam A, Bikoff EK, Robertson EJ: Dose-dependent Smad1, Smad5 and Smad8 signaling in the early mouse embryo. Dev Biol 2006, 296:104-118.

35. Huang Z, Wang DG, Ihida-Stansbury K, Jones PL, Martin JF: Defective pulmonary vascular remodeling in Smad8 mutant mice. Hum Mol Genet 2009, 18:2791-2801.

36. Tomic D, Miller KP, Kenny HA, Woodruff TK, Hoyer P, Flaws JA: Ovarian follicle development requires Smad3. Mol Endocrinol 2004, 18:2224-2240.

37. Gong X, McGee EA: Smad3 is required for normal follicular folliclestimulating hormone responsiveness in the mouse. Biol Reprod 2009, 81:730-738

38. Li Q, Pangas SA, Jorgez CJ, Graff JM, Weinstein M, Matzuk MM: Redundant roles of SMAD2 and SMAD3 in ovarian granulosa cells in vivo. Mol Cell Biol 2008, 28:7001-7011.

39. Pangas SA, Li X, Robertson EJ, Matzuk MM: Premature luteinization and cumulus cell defects in ovarian-specific Smad4 knockout mice. Mol Endocrinol 2006, 20:1406-1422.

40. Li X, Tripurani SK, James R, Pangas SA: Minimal fertility defects in mice deficient in oocyte-expressed Smad4. Biol Reprod 2012, 86:1-6. 
41. Quezada M, Wang J, Hoang V, McGee EA: Smad7 is a transforming growth factor-beta-inducible mediator of apoptosis in granulosa cells. Fertil Steril 2012, 97:1452-1459. e1451-1456.

42. Gao Y, Wen H, Wang C, Li Q: SMAD7 antagonizes key TGFbeta superfamily signaling in mouse granulosa cells in vitro. Reproduction 2013, 146:1-11.

43. Li Q, Agno JE, Edson MA, Nagaraja AK, Nagashima T, Matzuk MM: Transforming growth factor beta receptor type 1 is essential for female reproductive tract integrity and function. PLoS Genet 2011, 7:e1002320.

44. Gao Y, Bayless KJ, Li Q: TGFBR1 is required for mouse myometrial development. Mol Endocrinol 2014, 28:380-394.

45. Clementi C, Tripurani SK, Large MJ, Edson MA, Creighton CJ, Hawkins SM, Kovanci E, Kaartinen V, Lydon JP, Pangas SA, DeMayo FJ, Matzuk MM: Activin-like kinase 2 functions in peri-implantation uterine signaling in mice and humans. PLoS Genet 2013, 9:e1003863.

46. Nagashima T, Li Q, Clementi C, Lydon JP, Demayo FJ, Matzuk MM: BMPR2 is required for postimplantation uterine function and pregnancy maintenance. J Clin Invest 2013, 123:2539-2550.

47. Orvis GD, Behringer RR: Cellular mechanisms of Mullerian duct formation in the mouse. Dev Biol 2007, 306:493-504.

48. Brody JR, Cunha GR: Histologic, morphometric, and immunocytochemical analysis of myometrial development in rats and mice: I. Normal development. Am J Anat 1989, 186:1-20.

49. Brody JR, Cunha GR: Histologic, morphometric, and immunocytochemical analysis of myometrial development in rats and mice: II. Effects of DES on development. Am J Anat 1989, 186:21-42

50. Miller C, Sassoon DA: Wnt-7a maintains appropriate uterine patterning during the development of the mouse female reproductive tract. Development 1998, 125:3201-3211.

51. Wang $Y$, Jia $Y$, Franken $P$, Smits R, Ewing PC, Lydon JP, Demayo FJ, Burger CW, Anton Grootegoed J, Fodde R, Blok L: Loss of APC function in mesenchymal cells surrounding the Mullerian duct leads to myometrial defects in adult mice. Mol Cell Endocrinol 2011, 341:48-54.

52. Arango NA, Szotek PP, Manganaro TF, Oliva E, Donahoe PK, Teixeira J: Conditional deletion of beta-catenin in the mesenchyme of the developing mouse uterus results in a switch to adipogenesis in the myometrium. Dev Biol 2005, 288:276-283.

53. Parr BA, McMahon AP: Sexually dimorphic development of the mammalian reproductive tract requires Wnt-7a. Nature 1998, 395:707-710.

54. Mesiano S, Chan EC, Fitter JT, Kwek K, Yeo G, Smith R: Progesterone withdrawal and estrogen activation in human parturition are coordinated by progesterone receptor A expression in the myometrium. J Clin Endocrinol Metab 2002, 87:2924-2930.

55. Condon JC, Jeyasuria P, Faust JM, Wilson JW, Mendelson CR: A decline in the levels of progesterone receptor coactivators in the pregnant uterus at term may antagonize progesterone receptor function and contribute to the initiation of parturition. Proc Natl Acad Sci U S A 2003, 100:9518-9523.

56. Brainard AM, Miller AJ, Martens JR, England SK: Maxi-K channels localize to caveolae in human myometrium: a role for an actin-channel-caveolin complex in the regulation of myometrial smooth muscle $\mathrm{K}+$ current. Am J Physiol Cell Physiol 2005, 289:C49-C57.

57. Brainard AM, Korovkina VP, England SK: Potassium channels and uterine function. Semin Cell Dev Biol 2007, 18:332-339.

58. Pierce SL, Kresowik JD, Lamping KG, England SK: Overexpression of SK3 channels dampens uterine contractility to prevent preterm labor in mice. Bio Reprod 2008, 78:1058-1063.

59. Pierce SL, England SK: SK3 channel expression during pregnancy is regulated through estrogen and Sp factor-mediated transcriptional control of the KCNN3 gene. Am J Physiol Endocrinol Metab 2010, 299:E640-E646.

60. Yallampalli C, Dong YL: Estradiol-17beta inhibits nitric oxide synthase (NOS)-II and stimulates NOS-III gene expression in the rat uterus. Bio Reprod 2000, 63:34-41.

61. Yallampalli C, Garfield RE, Byam-Smith M: Nitric oxide inhibits uterine contractility during pregnancy but not during delivery. Endocrinology 1993, 133:1899-1902.

62. Yallampalli C, Izumi H, Byam-Smith M, Garfield RE: An L-arginine-nitric oxide-cyclic guanosine monophosphate system exists in the uterus and inhibits contractility during pregnancy. Am J Obstet Gynecol 1994, 170:175-185.

63. Dong $Y L$, Yallampalli C: Interaction between nitric oxide and prostaglandin E2 pathways in pregnant rat uteri. Am J Physiol 1996, 270:E471-E476.
64. Tong D, Lu X, Wang HX, Plante I, Lui E, Laird DW, Bai D, Kidder GM: A dominant loss-of-function GJA1 (Cx43) mutant impairs parturition in the mouse. Biol Reprod 2009, 80:1099-1106.

65. Renthal NE, Chen CC, Williams KC, Gerard RD, Prange-Kiel J, Mendelson CR: miR-200 family and targets, ZEB1 and ZEB2, modulate uterine quiescence and contractility during pregnancy and labor. Proc Natl Acad SCl U S A 2010, 107:20828-20833.

66. Williams KC, Renthal NE, Gerard RD, Mendelson CR: The microRNA (miR)-199a/214 cluster mediates opposing effects of progesterone and estrogen on uterine contractility during pregnancy and labor. Mol Endocrinol 2012, 26:1857-1867.

67. Cockburn K, Rossant J: Making the blastocyst: lessons from the mouse. J Clin Invest 2010, 120:995-1003.

68. Flach $\mathrm{G}$, Johnson MH, Braude PR, Taylor RA, Bolton VN: The transition from maternal to embryonic control in the 2-cell mouse embryo. Embo J 1982, 1:681-686.

69. Salamonsen LA, Dimitriadis E, Jones RL, Nie G: Complex regulation of decidualization: a role for cytokines and proteases-a review. Placenta 2003, 24(Suppl A):S76-S85.

70. Wang H, Dey SK: Roadmap to embryo implantation: clues from mouse models. Nat Rev Genet 2006, 7:185-199.

71. Cha J, Sun X, Dey SK: Mechanisms of implantation: strategies for successful pregnancy. Nat Med 2012, 18:1754-1767.

72. Guzelogiu-Kayisli Z, Kayisli UA, Taylor HS: The role of growth factors and cytokines during implantation: endocrine and paracrine interactions. Semin Reprod Med 2009, 27:62-79.

73. Memon MA, Anway MD, Covert TR, Uzumcu M, Skinner MK: Transforming growth factor beta (TGF beta 1, TGF beta 2 and TGF beta 3) null-mutant phenotypes in embryonic gonadal development. Mol Cell Endocrinol 2008, 294:70-80.

74. Mu Z, Yang Z, Yu D, Zhao Z, Munger JS: TGFbeta1 and TGFbeta3 are partially redundant effectors in brain vascular morphogenesis. Mech Dev 2008, 125:508-516.

75. Kallapur S, Ormsby I, Doetschman T: Strain dependency of TGFbeta1 function during embryogenesis. Mol Reprod Dev 1999, 52:341-349.

76. Ingman W, Robker RL, Woittiez K, Robertson SA: Null mutation in transforming growth factor beta1 disrupts ovarian function and causes oocyte incompetence and early embryo arrest. Endocrinology 2006, 147:835-845.

77. Paria BC, Dey SK: Preimplantation embryo development in vitro - Cooperative interactions among embryos and role of growth-factors. Proc Natl Acad Sci U S A 1990, 87:4756-4760.

78. Lim J, Bongso A, Ratnam S: Mitogenic and cytogenetic evaluation of transforming growth-factor-beta on murine preimplantation embryonic-development in-vitro. Mol Reprod Dev 1993, 36:482-487.

79. Nowak RA, Haimovici F, Biggers JD, Erbach GT: Transforming growth factorbeta stimulates mouse blastocyst outgrowth through a mechanism involving parathyroid hormone-related protein. Biol Reprod 1999, 60:85-93.

80. Feinberg RF, Kliman HJ, Wang CL: Transforming growth factor-beta stimulates trophoblast oncofetal fibronectin synthesis in vitro: implications for trophoblast implantation in vivo. J Clin Endocrinol Metab 1994, 78:1241-1248.

81. Graham CH, Connelly I, Macdougall JR, Kerbel RS, Stetlerstevenson WG, Lala PK: Resistance of malignant trophoblast cells to both the antiproliferative and anti-invasive effects of transforming growth-factor-beta. Exp Cell Res 1994, 214:93-99.

82. Letterio JJ, Geiser AG, Kulkarni AB, Roche NS, Sporn MB, Roberts AB: Maternal rescue of transforming growth factor-beta 1 null mice. Science 1994, 264:1936-1938.

83. McLennan IS, Koishi K: Fetal and maternal transforming growth factorbeta 1 may combine to maintain pregnancy in mice. Biol Reprod 2004, 70:1614-1618

84. Akinyemi BO, Adewoye BR, Fakoya TA: Uterine fibroid: a review. Niger J Med 2004, 13:318-329.

85. Dou Q, Zhao Y, Tarnuzzer RW, Rong H, Williams RS, Schultz GS, Chegini N: Suppression of transforming growth factor-beta (TGF beta) and TGF beta receptor messenger ribonucleic acid and protein expression in leiomyomata in women receiving gonadotropin-releasing hormone agonist therapy. J Clin Endocrinol Metab 1996, 81:3222-3230.

86. Arici A, Sozen I: Transforming growth factor-beta3 is expressed at high levels in leiomyoma where it stimulates fibronectin expression and cell proliferation. Fertil Steril 2000, 73:1006-1011. 
87. Levy G, Malik M, Britten J, Gilden M, Segars J, Catherino WH: Liarozole inhibits transforming growth factor-beta3-mediated extracellular matrix formation in human three-dimensional leiomyoma cultures. Fertil Steril 2014, 102:272-281.

88. Joseph DS, Malik M, Nurudeen S, Catherino WH: Myometrial cells undergo fibrotic transformation under the influence of transforming growth factor beta-3. Fertil Steril 2010, 93:1500-1508.

89. Malik $M$, Catherino WH: Development and validation of a three-dimensional in vitro model for uterine leiomyoma and patient-matched myometrium. Fertil Steril 2012, 97:1287-1293.

90. Malik M, Catherino WH: Novel method to characterize primary cultures of leiomyoma and myometrium with the use of confirmatory biomarker gene arrays. Fertil Steril 2007, 87:1166-1172.

91. Luo X, Ding L, Chegini N: CCNs, fibulin-1C and S100A4 expression in leiomyoma and myometrium: inverse association with TGF-beta and regulation by TGF-beta in leiomyoma and myometrial smooth muscle cells. Mol Hum Reprod 2006, 12:245-256.

92. Levens E, Luo X, Ding L, Williams RS, Chegini N: Fibromodulin is expressed in leiomyoma and myometrium and regulated by gonadotropinreleasing hormone analogue therapy and TGF-beta through Smad and MAPK-mediated signalling. Mol Hum Reprod 2005, 11:489-494.

93. Norian JM, Malik M, Parker CY, Joseph D, Leppert PC, Segars JH, Catherino WH: Transforming growth factor beta3 regulates the versican variants in the extracellular matrix-rich uterine leiomyomas. Reprod Sci 2009, 16:1153-1164.

94. Di X, Andrews DM, Tucker CJ, Yu L, Moore AB, Zheng X, Castro L, Hermon T, Xiao $H$, Dixon D: A high concentration of genistein down-regulates activin A, Smad3 and other TGF-beta pathway genes in human uterine leiomyoma cells. Exp Mol Med 2012, 44:281-292.

95. Li Z, Burzawa JK, Troung A, Feng S, Agoulnik IU, Tong X, Anderson ML, Kovanci E, Rajkovic A, Agoulnik Al: Relaxin signaling in uterine fibroids. Ann N Y Acad Sci 2009, 1160:374-378.

96. Grudzien MM, Low PS, Manning PC, Arredondo M, Belton RJ Jr, Nowak RA: The antifibrotic drug halofuginone inhibits proliferation and collagen production by human leiomyoma and myometrial smooth muscle cells. Fertil Steril 2010, 93:1290-1298.

97. Ohara N, Morikawa A, Chen W, Wang J, DeManno DA, Chwalisz K, Maruo T: Comparative effects of SPRM asoprisnil (J867) on proliferation, apoptosis, and the expression of growth factors in cultured uterine leiomyoma cells and normal myometrial cells. Reprod Sci 2007, 14:20-27.

98. De Falco M, Staibano S, D'Armiento FP, Mascolo M, Salvatore G, Busiello A, Carbone IF, Pollio F, Di Lieto A: Preoperative treatment of uterine leiomyomas: Clinical findings and expression of transforming growth factor-beta 3 and connective tissue growth factor. J Soc Gynecol Investig 2006, 13:297-303.

99. Sinclair DC, Mastroyannis A, Taylor HS: Leiomyoma simultaneously impair endometrial BMP-2-mediated decidualization and anticoagulant expression through secretion of TGF-beta 3. J Clin Endocr Metab 2011, 96:412-421.

100. Peracoli MT, Menegon FT, Borges VT, de Araujo Costa RA, Thomazini-Santos IA, Peracoli JC: Platelet aggregation and TGF-beta(1) plasma levels in pregnant women with preeclampsia. J Reprod Immunol 2008, 79:79-84.

101. Djurovic S, Schjetlein R, Wisloff F, Haugen G, Husby H, Berg K: Plasma concentrations of $L p(a)$ lipoprotein and TGF-beta1 are altered in preeclampsia. Clin Genet 1997, 52:371-376.

102. Enquobahrie DA, Williams MA, Qiu C, Woelk GB, Mahomed K: Maternal plasma transforming growth factor-beta1 concentrations in preeclamptic and normotensive pregnant Zimbabwean women. J Matern Fetal Neona 2005, 17:343-348.

103. Wang XJ, Zhou ZY, Xu YJ: Changes of plasma uPA and TGF-beta1 in patients with preeclampsia. Sichuan Da Xue Xue Bao Yi Xue Ban 2010, 41:118-120.

104. Feizollahzadeh S, Taheripanah R, Khani M, Farokhi B, Amani D: Promoter region polymorphisms in the transforming growth factor beta-1 (TGFbeta1) gene and serum TGFbeta1 concentration in preeclamptic and control Iranian women. J Reprod Immunol 2012, 94:216-221.

105. Shaarawy M, El Meleigy M, Rasheed K: Maternal serum transforming growth factor beta- 2 in preeclampsia and eclampsia, a potential biomarker for the assessment of disease severity and fetal outcome. J Soc Gynecol Investig 2001, 8:27-31.

106. Caniggia I, Grisaru-Gravnosky S, Kuliszewsky M, Post M, Lye SJ: Inhibition of TGF-beta 3 restores the invasive capability of extravillous trophoblasts in preeclamptic pregnancies. J Clin Invest 1999, 103:1641-1650.
107. Venkatesha S, Toporsian M, Lam C, Hanai J, Mammoto T, Kim YM, Bdolah Y, Lim KH, Yuan HT, Libermann TA, Stillman IE, Roberts D, D'Amore PA, Epstein FH, Sellke FW, Romero R, Sukhatme VP, Letarte M, Karumanchi SA: Soluble endoglin contributes to the pathogenesis of preeclampsia. Nat Med 2006, 12:642-649.

108. Stepan H, Kramer T, Faber R: Maternal plasma concentrations of soluble endoglin in pregnancies with intrauterine growth restriction. J Clin Endocrinol Metab 2007, 92:2831-2834.

109. Lyall F, Simpson H, Bulmer JN, Barber A, Robson SC: Transforming growth factor-beta expression in human placenta and placental bed in third trimester normal pregnancy, preeclampsia, and fetal growth restriction. Am J Pathol 2001, 159:1827-1838.

110. Szarka A, Rigo J Jr, Lazar L, Beko G, Molvarec A: Circulating cytokines, chemokines and adhesion molecules in normal pregnancy and preeclampsia determined by multiplex suspension array. BMC Immunol 2010, 11:59

111. Perucci LO, Gomes KB, Freitas LG, Godoi LC, Alpoim PN, Pinheiro MB, Miranda AS, Teixeira AL, Dusse LM, Sousa LP: Soluble endoglin, transforming growth factor-Beta 1 and soluble tumor necrosis factor alpha receptors in different clinical manifestations of preeclampsia. PLoS One 2014, 9:e97632

112. Huber A, Hefler L, Tempfer C, Zeisler H, Lebrecht A, Husslein P: Transforming growth factor-beta 1 serum levels in pregnancy and pre-eclampsia. Acta Obstet Gynecol Scand 2002, 81:168-171.

113. Bersinger NA, Smarason AK, Muttukrishna S, Groome NP, Redman CW: Women with preeclampsia have increased serum levels of pregnancyassociated plasma protein a (PAPP-A), inhibin A, activin A, and soluble Eselectin. Hypertens Pregnancy 2003, 22:45-55.

114. Silver HM, Lambert-Messerlian GM, Reis FM, Diblasio AM, Petraglia F, Canick $J A$ : Mechanism of increased maternal serum total activin $A$ and inhibin $A$ in preeclampsia. J Soc Gynecol Investig 2002, 9:308-312.

115. Yair D, Eshed-Englender T, Kupferminc MJ, Geva E, Frenkel J, Sherman D: Serum levels of inhibin $B$, unlike inhibin $A$ and activin $A$, are not altered in women with preeclampsia. Am J Reprod Immunol 2001, 45:180-187.

116. Laivuori H, Kaaja R, Turpeinen U, Stenman UH, Ylikorkala O: Serum activin A and inhibin A elevated in pre-eclampsia: no relation to insulin sensitivity. BJOG 1999, 106:1298-1303.

117. Figueras F, Gardosi J: Intrauterine growth restriction: new concepts in antenatal surveillance, diagnosis, and management. Am J Obstet Gynecol 2011, 204:288-300.

118. Ostlund E, Tally M, Fried G: Transforming growth factor-beta1 in feta serum correlates with insulin-like growth factor-I and fetal growth. Obstet Gynecol 2002, 100:567-573.

119. Sanford LP, Ormsby I, GittenbergerdeGroot AC, Sariola H, Friedman R, Boivin GP, Cardell EL, Doetschman T: TGF beta 2 knockout mice have multiple developmental defects that are nonoverlapping with other TGF beta knockout phenotypes. Development 1997, 124:2659-2670.

120. Jeyabalan A, McGonigal S, Gilmour C, Hubel CA, Rajakumar A: Circulating and placental endoglin concentrations in pregnancies complicated by intrauterine growth restriction and preeclampsia. Placenta 2008, 29:555-563.

121. Yinon Y, Nevo O, Xu J, Many A, Rolfo A, Todros T, Post M, Caniggia I: Severe intrauterine growth restriction pregnancies have increased placental endoglin levels: hypoxic regulation via transforming growth factor-beta 3. Am J Pathol 2008, 172:77-85.

122. Park CB, DeMayo FJ, Lydon JP, Dufort D: NODAL in the uterus is necessary for proper placental development and maintenance of pregnancy. Biol Reprod 2012, 86:194.

123. Mills AM, Longacre TA: Endometrial hyperplasia. Semin Diagn Pathol 2010, 27:199-214

124. Kurman RJ, Kaminski PF, Norris HJ: The behavior of endometrial hyperplasia. A long-term study of "untreated" hyperplasia in 170 patients. Cancer 1985, 56:403-412.

125. Montgomery BE, Daum GS, Dunton CJ: Endometrial hyperplasia: a review. Obstet Gynecol Surv 2004, 59:368-378.

126. Shutter J, Wright TC: Prevalence of underlying adenocarcinoma in women with atypical endometrial hyperplasia. Int J Gynecol Pathol 2005, 24:313-318.

127. Lacey JV, Chia VM: Endometrial hyperplasia and the risk of progression to carcinoma. Maturitas 2009, 63:39-44.

128. Hahn HS, Chun YK, Kwon Yl, Kim TJ, Lee KH, Shim JU, Mok JE, Lim KT: Concurrent endometrial carcinoma following hysterectomy for atypical endometrial hyperplasia. Eur J Obstet Gynecol Reprod Biol 2010, 150:80-83. 
129. Gambrell RD: Progestogens in estrogen-replacement therapy. Clin Obstet Gynecol 1995, 38:890-901.

130. Reed SD, Voigt LF, Newton KM, Garcia RH, Allison HK, Epplein M, Jordan D, Swisher E, Weiss NS: Progestin therapy of complex endometrial hyperplasia with and without atypia. Obstet Gynecol 2009, 113:655-662.

131. Stambolic V, Tsao MS, Macpherson D, Suzuki A, Chapman WR, Mak TW: High incidence of breast and endometrial neoplasia resembling human Cowden syndrome in pten(+/-) mice. Cancer Res 2000, 60:3605-3611.

132. Milam MR, Soliman PT, Chung LH, Schmeler KM, Bassett RL, Broaddus RR, Lu $\mathrm{KH}$ : Loss of phosphatase and tensin homologue deleted on chromosome 10 and phosphorylation of mammalian target of rapamycin are associated with progesterone refractory endometrial hyperplasia. Int J Gynecol Cancer 2008, 18:146-151.

133. Parekh TV, Gama P, Wen X, Demopoulos R, Munger JS, Carcangiu ML, Reiss M, Gold Ll: Transforming growth factor beta signaling is disabled early in human endometrial carcinogenesis concomitant with loss of growth inhibition. Cancer Res 2002, 62:2778-2790.

134. Lecanda J, Parekh TV, Gama P, Lin K, Liarski V, Uretsky S, Mittal K, Gold LI: Transforming growth factor-beta, estrogen, and progesterone converge on the regulation of p27Kip1 in the normal and malignant endometrium. Cancer Res 2007, 67:1007-1018.

135. Piestrzeniewicz-Ulanska D, McGuinness D, Yeaman G: TGF- $\beta$ Signaling in Endometrial Cancer. In Transforming Growth Factor- $\beta$ in Cancer Therapy, Volume II. Edited by Jakowlew S. Totowa, NJ: Humana Press; 2008:63-78.

136. Gao Y, Li S, Li Q: Uterine epithelial cell proliferation and endometrial hyperplasia: evidence from a mouse model. Mol Hum Reprod 2014, 20:776-786

doi:10.1186/2049-1891-5-52

Cite this article as: Li: Transforming growth factor $\beta$ signaling in uterine development and function. Journal of Animal Science and Biotechnology 2014 5:52.

\section{Submit your next manuscript to BioMed Central and take full advantage of:}

- Convenient online submission

- Thorough peer review

- No space constraints or color figure charges

- Immediate publication on acceptance

- Inclusion in PubMed, CAS, Scopus and Google Scholar

- Research which is freely available for redistribution 